\title{
O DIFÍCIL INÍCIO DA CARREIRA
}

Em geral, tomar decisões sobre a carreira não é fácil; e pode ser mais difícil quando se está no início da vida profissional. Isso é compreensível, pois quanto menos experiência no trabalho um indivíduo tem, menor é o seu conhecimento sobre seus próprios gostos, competências, valores e expectativas, elementos essenciais para a tomada de decisão sobre a carreira profissional. Na verdade, para muitas pessoas, os primeiros passos na carreira são dados sem que nenhum desses fatores seja levado em consideração, uma vez que, para obter o primeiro emprego, não se tem quase nenhuma informação para se fazer essa escolha.

Não é por acaso, portanto, que a primeira experiência no trabalho pode ser desapontadora; a pessoa sente-se frustrada e, em grande medida, perdida. E as experiências que seguem podem não ser muito diferentes. Na verdade, para um grande número de pessoas, a fase inicial da carreira parece ser marcada por dúvidas e angústias quanto às escolhas feitas; acrescem-se a elas, ainda, as dificuldades inerentes ao aprender a trabalhar, ou seja, aprender a parte técnica do trabalho, a trabalhar com líderes e colegas, aprender a cultura, as normas e regras da organização, e assim por diante. Temos aí os ingredientes que podem fazer desse um período bastante desgastante da vida profissional.

Dadas as dificuldades, essas pessoas começam um movimento de experimentação, ou seja, saem em busca de algo melhor, mas que não sabem bem o que é. Sem planejamento adequado, acabam trocando de emprego ou área de maneira aleatória, baseadas mais no feeling ou no aconselhamento de amigos ou parentes. Fazem cursos formais de especialização ou pós-gradua- ção, na esperança de encontrar um caminho para a carreira. $\mathrm{Na}$ verdade, saem dando tiros para todos os lados, na tentativa de descobrir onde estão os empregos no mercado. Por outro lado, têm receio do que o mercado poderá pensar de seus currículos, com inúmeras experiências de curta duração em áreas que parecem desconexas.

Surge, então, o questionamento: essa experimentação é válida? Sim, pode ser válida e benéfica para a vida profissional, mas precisa ser bem gerenciada. É bom lembrar que, especialmente na fase inicial da carreira, cada novo trabalho é uma fonte rica de exploração dos próprios gostos, aptidões e competências pessoais. No entanto, é importante que essa exploração seja transformada em informação sobre as expectativas da vida profissional, ou seja, é dessa maneira que cada nova experiência de trabalho adquire sentido e contribui para o rumo do percurso profissional do indivíduo.

Para isso, é preciso haver a avaliação de cada experiência e o planejamento dos passos seguintes. São esses processos que permitirão que a riqueza de cada vivência no trabalho seja colocada na perspectiva da vida profissional. É a avaliação de cada experiência e a sua inserção em um planejamento da carreira que vão permitir que os conhecimentos adquiridos se integrem e que uma história seja contada: a história da carreira profissional. Ainda que seja com muita movimentação e, aparentemente, em trabalhos em áreas distintas, cada vivência terá um desempenho e um papel importante. É essa avaliação da experiência conquistada e o planejamento futuro que fazem com que se tenha mais do que apenas histórias isoladas e fragmentadas.

\section{PROJETO $\nabla$ DE VIDA}

$\mathrm{Na}$ fase inicial da carreira, cada novo trabalho é uma fonte rica de exploração dos próprios gostos, aptidões e competências pessoais

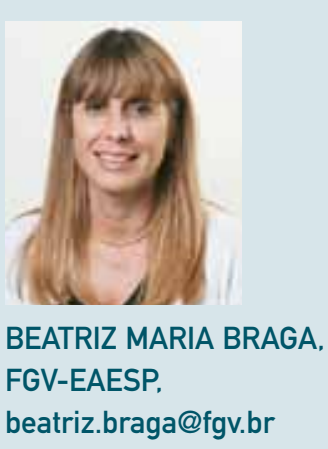

